\title{
Analisa Pengaruh Beban Linier Dan Beban Non Linier Terhadap Fungsi Kerja Miniature Circuit Breaker
}

\author{
Juhana \\ Prodi Teknik Elektro FT UNPAM \\ Jln. Puspiptek Raya No 46Buaran, Tangerang Selatan 15310 INDONESIA \\ 1Juhana12345@gmail.com
}

\begin{abstract}
ABSTRAK
Beban listrik adalah suatu perangkat alat yang dapat berfungsi jika dialiri arus listrik. Perangkat alat tersebut digunakan untuk merubah energi listrik menjadi energi lain misalnya gerak, panas, cahaya dan lain sebagainya. Beban listrik terdiri dari beban linier dan beban non linier. Meningkatnya penggunaan beban non linier antara lain contohnya motor induksi, penyearah, static power converter (rectifiers atau inverters), ballast elektronik menyebabkan timbulnya harmonisa. Harmonisa merupakan gelombang sinusoidal dengan frekuensi yang merupakan kelipatan bulat dari frekuensi fundamentalnya. Harmonisa dapat mempengaruhi fungsi kerja miniature circuit breaker (MCB) yaitu menimbulkan pemanasan lebih pada bimetal sehingga terjadi abnormal pada proses pemutusan rangkaian. Untuk perbandingan penelitian ini juga dilakukan pengujian menggunakan beban linier berupa lampu pijar dan elemen pemanas, sedangkan untuk pengujian dengan beban non linier berupa motor induksi. Arus yang dialirkan sebesar 1,5 x In MCB. Dari penelitian yang dilakukan harmonisa mempengaruhi fungsi kerja MCB dimana besaran distorsi harmonisa (THD) mempengaruhi waktu pemutusan rangkaian oleh MCB menjadi lebih cepat, seperti pada pengujian beban non linier yaitu membutuhkan waktu 48 detik sedangkan pada pengujian beban linier membutuhkan waktu 127 detik.
\end{abstract}

Kata kunci :Beban non linier dan beban linier, miniature circuit breaker (MCB), Total Harmonik distortion (THD).

\begin{abstract}
Electrical load is a tool device that can function if the flow of electricity. Device tool is used to convert electrical energy into other energies such as motion, heat, light and so forth. Electrical load consists of linear load and non linear load. Increased use of non-linear loads, for example induction motors, rectifiers, static power converters (rectifiers or inverters), electronic ballasts cause the emergence of harmonics. Harmonic is a sinusoidal wave with a frequency that is a multiple of its fundamental frequency. Harmonics can affect the work function of miniature circuit breaker (MCB) that causes more heating on the bimetal so that it occurs abnormally in the process of disconnection of the circuit. For comparison this research also tested using linear load of incandescent lamp and heating element, while for testing with non linear load in the form of induction motor. Streamed current of $1.5 \mathrm{x}$ In MCB. From research conducted harmonics affects the work function of MCB where the amount of harmonic distortion (THD) affects the breaking time of the circuit by MCB becomes faster, as in non linear load testing that takes 48 seconds while in linear load testing takes 127 seconds.
\end{abstract}

Keywords : Non linier load and Linier load, miniature circuit breaker (MCB), Total Harmonik distortion (THD). 


\section{PENDAHULUAN}

Sistem distribusi tenaga listrik yang ideal $\mathrm{S}$ adalah energi listrik disalurkan dalam frekuensi tunggal yang konstan dan pada level tegangan yang konstan pula.

Tetapi dengan berjalannya waktu perkembangan teknologi peralatan yang menggunakan tenaga listrik semakin pesat dan variatif, terutama peralatan listrik beban non linier, ini menimbulkan permasalahan karena memunculkan harmonisa sehingga gelombang arus dan tegangan menjadi cacat dan tidak sinusoidal lagi akibat dari interaksi gelombang sinus sistem dengan gelombang sinus lain yang berfrekuensi tinggi yang merupakan kelipatan dari frekuensi fundamentalnya berakibat mutu daya listrik menjadi menurun.

Miniature Circuit Breaker (MCB) berfungsi untuk membatasi arus atau pengaman beban lebih, sekaligus berfungsi sebagai pengaman hubung singkat (konsleting). MCB akan secara otomatis dengan segera memutuskan arus, apabila arus yang melewatinya melebihi dari arus nominal yang telah ditentukan, MCB akan segera memutus rangkaian jika terjadi hubung singkat. Dalam hal ini apakah beban non linier mempengaruhi fungsi kerja MCB sehingga beroperasi secara tidak benar, jika hal ini terjadi tentunya akan membahayakan bagi instalasi ataupun pada peralatan listrik yang berhubungan dalam rangkaian tersebut karena adanya kegagalan fungsi kerja MCB untuk melakukan pemutusan daya listrik, maka dalam penelitian ini akan dilakukan pengujian $\mathrm{MCB}$, dengan pembebanan beban non linier dan pembebanan beban linier untuk membandingkan pengaruh terhadap fungsi kerjanya. Adapun MCB yang digunakan dalam pengujian ini adalah MCB 3 phasa rating arus nominal 2 Ampere.

\section{METODOLOGI}

\section{Bahan dan Alat yang dipergunakan didalam penelitian ini sebagai berikut}

\section{Alat}

Alat yang digunakan untuk pengujian beban linier dan beban non linier sebagai berikut: a. 1set NI MyDaqmerk USB 6009
b.Miniature Circuit Breaker (MCB) 3 Phasa

2A, merk Scheneider

c . Cosphi meter , merk FORT, OB-96

d. Frekwensimeter, merk FORT-OB-96.

220Volt

d. Timer Digital, merk AOTONIC LE8N-BF 24-240 VAC

e.Watt meter,merk Fort.600/5A.400 Volt

f.Ampere mter, merk FORT.OB.45

\section{Bahan}

Bahan pengujian untuk beban non linier adalah

1. unit motor induksi 3 phasa $1,5 \mathrm{~kW}$,dan 1.unit motor induksi 3 phasa $0,18 \mathrm{~kW}$ dipasang secara paralel,sedangkan bahan untuk beban Linier adalah

1. enam buah elamen pemanas @ 0,2 kW 2.enam buah lampu pijar 40 watt dan enam buah lampu pijar 60 watt sebagai beban resitif.

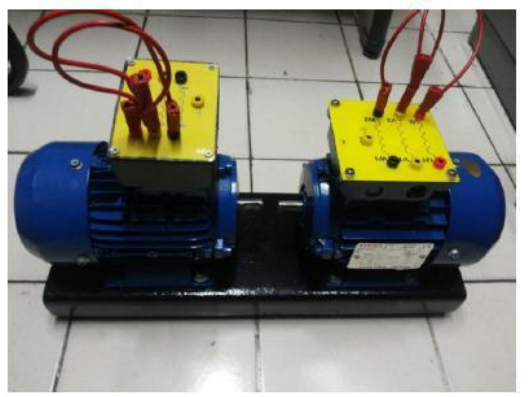

Gambar 1 .Motor Induksi sebagi beban non linier

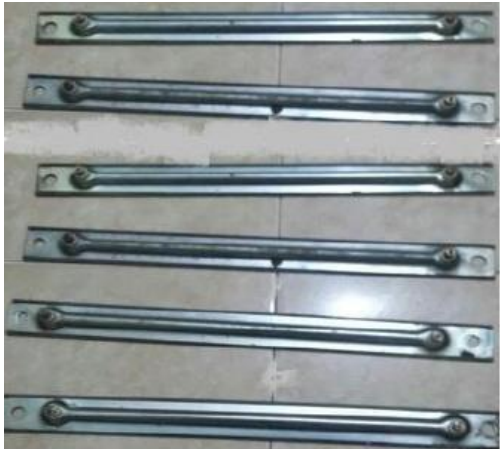

Gambar 2 Elemen Pemanas sebanyak 6 buah 


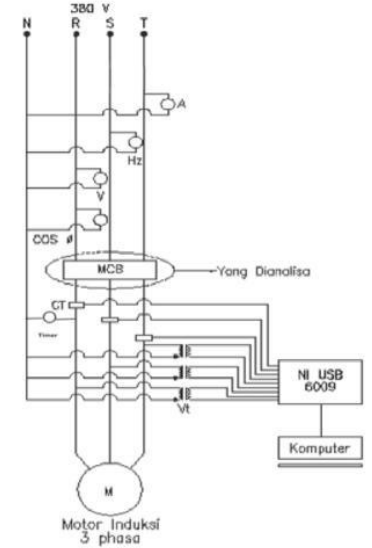

Gambar3 . Rangkaian beban non linier

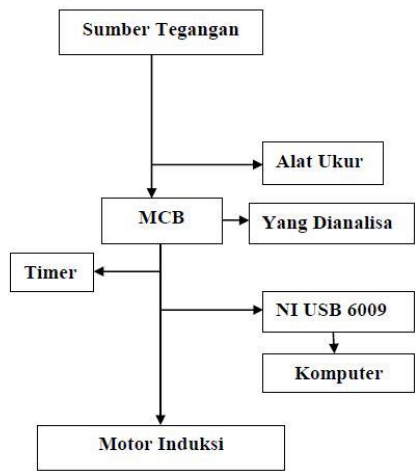

Gambar 4 Blok Diagram pengujian beban non linier

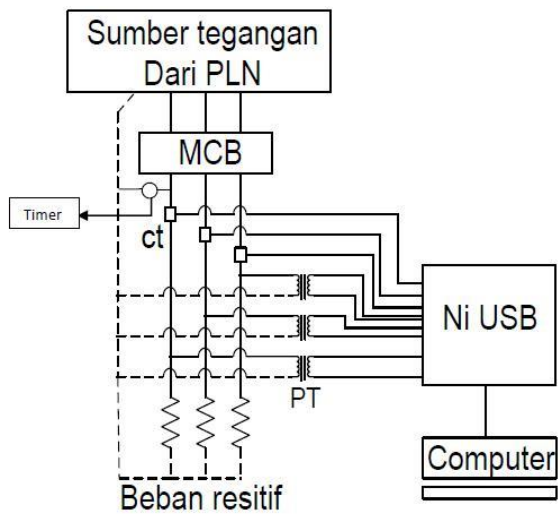

Gambar 5.Rangkaian pengujian beban linier.

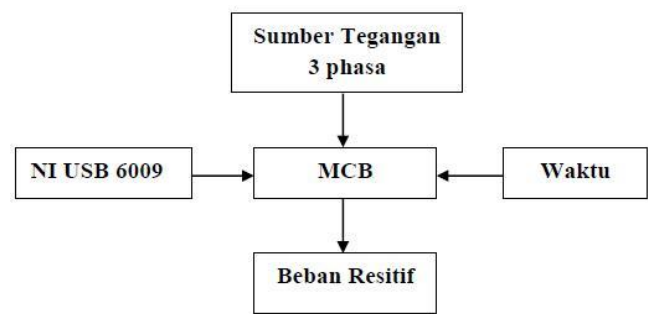

Gambar 6. Blok diagram pengujian

\section{Tata Kerja}

Tata kerja pengujian beban non linier sebagai berikut:

a.Menyiapkan dan memasang peralatan sesuai rangkaian gambar 2 .

b. Menyiapkan Virtual Instrument NI USB 6009 dan program LabVIEW untuk pelakukan pengukuran harmonisa arus dan tegangan.

c. Posisi Timer digital dimulai dari angka nol sebelum MCB di hidupkan.

d. Menghidupkan MCB 3Phasa 2A sesuai gambar.3 dan gambar4, dengan beban motor induksi

e. Pengukuran Total Harmonic Distortion (THD) arus dan tegangan, dan lamanya waktu yang dibutuhkan MCB untuk memutuskan rangkaian jika diberi arus melebihi arus nominal (In) $3 \mathrm{~A}$

\section{Tata kerja pengujian beban linier}

Untuk langkah pengujian beban linier secara terperinci adalah sebagai berikut:

a. Menyiapkan dan memasang semua peralatan sesuai rancangan.

b. Menyiapkan Virtual Instrument NI USB 6009 dan program LabVIEW untuk melakukan pengukuran harmonisa arus dan tegangan.

c. Langkah pengujian selanjutnya sesuai rangkaian pada gambar 3 dan gambar4 adalah menghidupkan MCB 3phasa 2A dengan beban linier berupa elemen pemanas ( heater) dan lampu pijar.

d. Posisi Timer digital dimulai dari angka nol sebelum MCB di hidupkan.

e. Hidupkan MCB dalam kondisi karakteristik dingin.

f. Pengambilan data untuk dianalisa pengaruh beban linier terhadap fungsi kerja MCB perihal berapa lamanya waktu yang dibutuhkan MCB untuk memutuskan rangkaian jika diberi beban melebihi arus nominal (In) 3 A. 


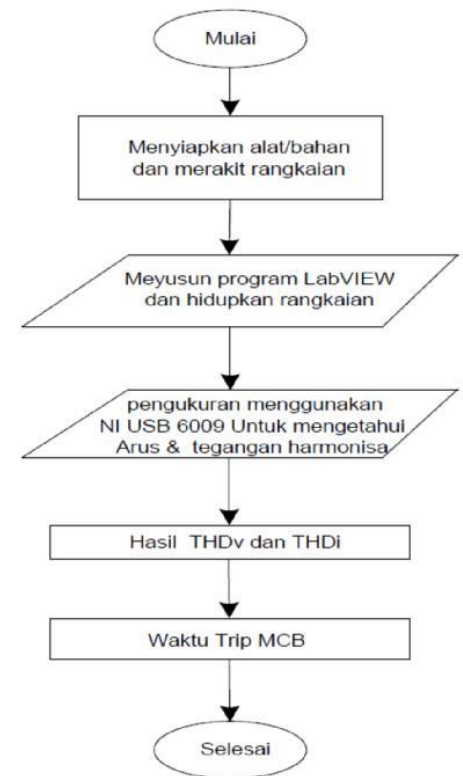

Gambar 7. Flow Chart Penelitian

\section{HASIL DAN PEMBAHASAN}

\section{Uji Banding pengukuran $\mathrm{Ni}$ USb dan Voltmeter}

Sebelum Ni USB dipergunakan terlebih dahulu dilakukan pengecekan yaitu uji banding antara Ni USB dan Voltmter hasil pengujian seperti terlihat pada tabel1

Tabel 1 Hasil uji tegangan Ni.USB dan Voltmeter

\begin{tabular}{|c|c|c|c|c|}
\hline \multirow{2}{*}{ No } & $\begin{array}{c}\text { Volt meter digital } \\
\text { Alat ukur acuan/rujukan }\end{array}$ & \multicolumn{3}{|c|}{ NI USB 6009 } \\
\cline { 2 - 5 } & Tegangan (V) & \multicolumn{3}{|c|}{ Tegangan (V) } \\
\cline { 2 - 5 } & $\mathrm{R}-\mathrm{S}-\mathrm{T}$ & $\mathrm{R}$ & $\mathrm{S}$ & $\mathrm{T}$ \\
\hline & 20,03 & 0,2834 & 0,2839 & 0,2838 \\
\hline 1 & 40,07 & 0,5609 & 0,5616 & 0,62 \\
\hline 2 & 60,05 & 0,8358 & 0,8371 & 0,8357 \\
\hline 3 & 80,04 & 1,118 & 1,12 & 1,119 \\
\hline 4 & 100,03 & 1,392 & 1,393 & 1,391 \\
\hline 5 & 120,02 & 1,677 & 1,677 & 1,675 \\
\hline 6 & 140,06 & 1,948 & 1,95 & 1,949 \\
\hline 7 & 160,01 & 2,229 & 2,23 & 2,227 \\
\hline 8 & 180,03 & 2,514 & 2,518 & 2,516 \\
\hline 9 & 200,06 & 2,836 & 2,84 & 2,837 \\
\hline 10 & 220,07 & 3,107 & 3,116 & 3,113 \\
\hline 11 & & & & \\
\hline
\end{tabular}

Dari hasil pengujian tegangan pada tabel1, selanjutnya menggunakan persamaan linier untuk melihat ke linieran alat ukur $\mathrm{Ni}$ USB dengan persamaan sebagai berikut:

\section{$y=m x+c$}

\section{Dimana :}

$y=$ Nilai pada alat ukur analog (digital volt meter).

$\mathrm{mx}=$ Gradien grafik dengan sumbu $(\mathrm{x})$.

$\mathrm{c}=$ Nilai konstanta pergeseran garis dari titik (0).

Dari tabel 1 selanjutnya dibuat grafik untuk melihat ke linieran nilai ukur NI USB seperti pada gambar grafik 8.

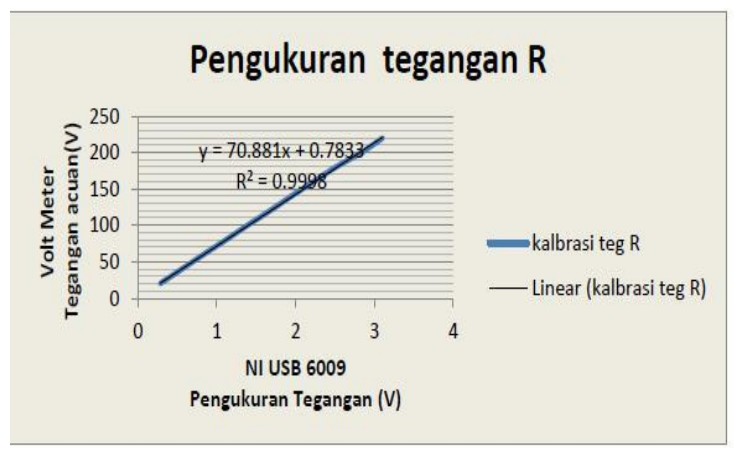

Gambar 8 Grafik Hasil uji banding tegangan Ni USB dengan Voltmeter.

Tabel2 Hasil uji besarnya arus Ni USB dan Voltmeter

\begin{tabular}{|c|c|c|c|c|}
\hline \multirow{3}{*}{ No } & \multirow{3}{*}{$\begin{array}{c}\text { Amper meter digital } \\
\text { Alat ukur acuan/rujukan } \\
\text { Arus (mA) }\end{array}$} & \multicolumn{3}{|c|}{$\begin{array}{l}\text { NI USB } 6009 \\
\text { yang mengacu/merujuk }\end{array}$} \\
\hline & & \multicolumn{3}{|c|}{ Arus $(m A)$} \\
\hline & & $R$ & $S$ & $T$ \\
\hline 1 & 100,03 & 0,034506 & 0,023802 & 0,031325 \\
\hline 2 & 200,04 & 0,08928 & 0,059134 & 0,083363 \\
\hline 3 & 300,06 & 0,153222 & 0,102949 & 0,145584 \\
\hline 4 & 400,02 & 0,217544 & 0,149137 & 0,207405 \\
\hline 5 & 500,01 & 0,285965 & 0,199801 & 0,274804 \\
\hline 6 & 600,07 & 0,356738 & 0,252787 & 0,344406 \\
\hline 7 & 700,05 & 0,43049 & 0,309823 & 0,420221 \\
\hline 8 & 800,03 & 0,50829 & 0,367306 & 0,497557 \\
\hline 9 & 900,06 & 0,593183 & 0,429545 & 0,585048 \\
\hline 10 & 1000,04 & 0,692262 & 0,500672 & 0,687767 \\
\hline
\end{tabular}

Dari hasil pengujian arus pada tabel2,

selanjutnya dibuat grafik gambar grafik 9 .

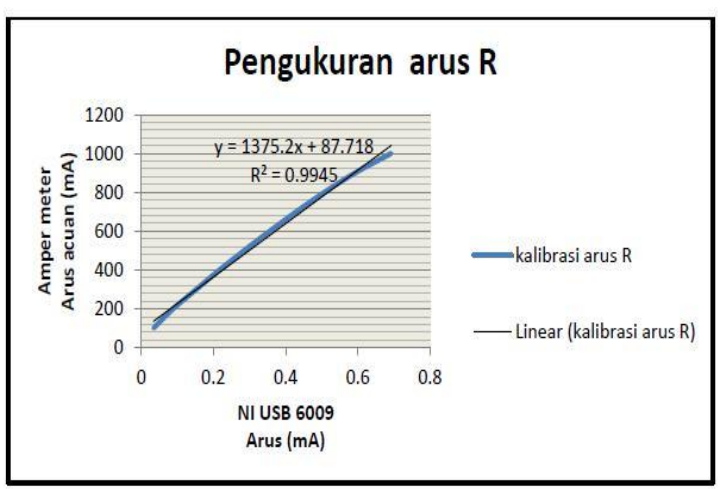


Gambar 9 Grafik hasil uji banding tegangan Ni USB dengan Voltmeter

Dari gambar grafik9, uji banding terlihat bahwa Linieritas tegangan dan arus Ni USB memenuhi syarat untuk dipergunakan.

\section{Hasil Pengujian Beban Non Linier Pengujian beban non linier 3 Amper} material yang dibutuhkan adalah 1 unit motor induksi 3 phasa $1,5 \mathrm{~kW}, 1$ unit motor induksi 3 phasa $0,18 \mathrm{~kW}$ dipasang secara paralel, adapun perhitungan arus beban adalah sebagai berikut :

Motor 1 daya $1,5 \mathrm{~kW}$ dan motor 2 = daya $0,18 \mathrm{~kW}$

Motor $1+$ Motor $2=1,5 \mathrm{~kW}+0,18 \mathrm{~kW}=$ $1,68 \mathrm{~kW}=1680$ Watt $, \operatorname{Cos} \varphi=0,85$

Dari persamaan Daya Listrik

$P=\sqrt{3} x V x I x \cos \varphi$

Maka arus listrik

$I=\frac{P}{\sqrt{3 x} v x \cos \varphi}$

$I=\frac{1680 \text { watt }}{\sqrt{3 \times 380 \times 0,85}}$

$I=3,006 \mathrm{~A}$

Hasil pengujian THDv, Vrms dan frekwensi dengan beban Non linier dapat dilihat pada tabel3.

Tabel3. Hasil pengujian THDv, $\mathrm{V}$ rms, dan f pada phasa $R, S$ dan $T$. dengan beban non linier

\begin{tabular}{|c|c|c|c|c|c|c|c|c|}
\hline \multicolumn{2}{|c|}{$\begin{array}{c}\text { Tegangan (RMS) } \\
\text { (Volt) }\end{array}$} & \multicolumn{3}{|c|}{$\begin{array}{c}\text { THDv } \\
(\%)\end{array}$} & \multicolumn{2}{c|}{$\begin{array}{c}\text { Frequensi } \\
\text { Tegangan } \\
\text { (Hz) }\end{array}$} \\
\hline R & S & T & R & S & T & R & S & T \\
\hline 283.3 & 228.3 & 281.3 & 7.87 & 11.8 & 6.23 & 50 & 50 & 50 \\
\hline
\end{tabular}

Pada tabel3 telihat hasil uji THDv terbesar pada phasa S, sebesar: $11,8 \%$ dan Vrms terbesar pada phasa $R$ sebesar 283.3 Volt,Dari hasil pengujian menunjukan bahwa kandungan harmonisa sudah melampaui standar yang ditetapkan oleh IEEE 519-1992 $<69 \mathrm{kV}$ yaitu sebesar $5 \%$.

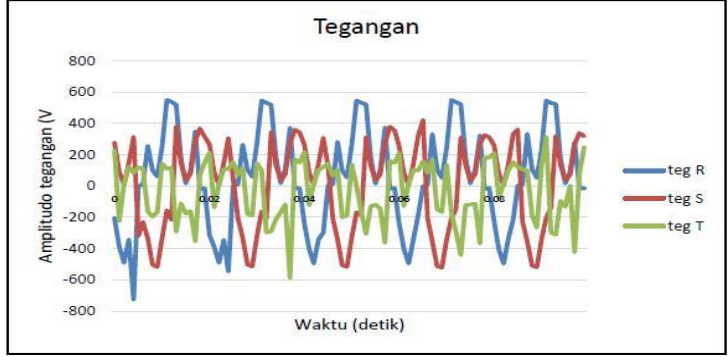

Gambar 10. Gelombang tegangan dengan beban non linier

Hasil pengujian THDi, Irms dan frekwensi dengan beban Non linier dapat dilihat pada tabel4.

Tabel 4 .Hasil Pengujian THDi dan waktu pada phasa $\mathrm{R}, \mathrm{S}$ dan $\mathrm{T}$ denagn beban non linier

\begin{tabular}{|c|c|c|c|c|c|c|c|c|c|}
\hline \multicolumn{3}{|c|}{$\begin{array}{c}\text { Arus (RMS) } \\
\text { (mA) }\end{array}$} & \multicolumn{3}{|c|}{$\begin{array}{l}\text { THDi } \\
(\%)\end{array}$} & \multicolumn{3}{|c|}{$\begin{array}{c}\text { Frequensy } \\
\text { Arus } \\
\text { (Hz) }\end{array}$} & \multirow{2}{*}{$\begin{array}{c}\text { Waktu } \\
\text { Pemutusan } \\
\text { MCB } \\
\text { (detik) }\end{array}$} \\
\hline $\mathbf{R}$ & & $T$ & $\mathbf{R}$ & $\mathrm{S}_{1}$ & T & $\mathbf{R}$ & $\mathrm{S}$ & $T$ & \\
\hline & 4583.7 & 2703 & 4.9 & 6.3 & 0 & 50 & 50 & 50 & 48 \\
\hline
\end{tabular}

Dari tabel 4. Terlihat bahwa hasil pengujian THDi terbesar pada phasa S sebesar $=6.3 \%$, Irms terbesar pada phasa $S$ sebesar $=4383.7$ $\mathrm{mA}$, dan waktu pemutusan MCBselama 48 detik

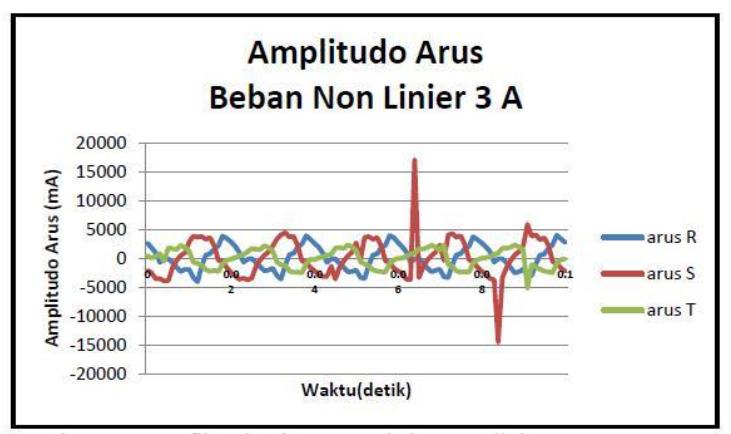

Gambar 11.Gëlombang Arus dengan beban non linier

\section{Hasil Pengujian Beban Linier}

Hasil pengujian Harmonik Tegangan dan Arus, seperti terlihat pada tabel 5. Untuk pengujian beban linier berupa beban Resitip 3 A material yang dibutuhkan adalah 6 buah elemen pemanas $0,2 \mathrm{~kW}$ di kombinasikan dengan 6 buah lampu pijar 100 Watt dan 3 buah lampu pijar 60 watt dipasang menggunakan rangkaian hubung bintang. dengan perhitungan arus beban adalah sebagai berikut

Elemen pemanas $=0,2 \mathrm{~kW} \times 6=1,2 \mathrm{~kW}$ $=1200 \mathrm{~W}$

Lampu pijar $=60 \mathrm{~W} \times 3=180 \mathrm{~W}$ dan Lampu pijar $=100 \mathrm{~W} \times 6=600 \mathrm{~W}$ denganCos $\varphi=1$ 
$I=\frac{1980 \text { watt }}{\sqrt{3 \times 380 \times 1}}$

Maka arus $(\mathrm{I})=3 \mathrm{~A}$

Hasil pengujian THDv, Vrms dan frekwensi dengan beban linier dapat dilihat pada tabel5

Tabel 5. Hasil pengujian Vrms, THDv dan $f$ pada phasa R,S dan T.dengan beban linier

\begin{tabular}{|c|c|c|c|c|c|c|c|c|}
\hline \multicolumn{2}{|c|}{$\begin{array}{c}\text { Tegangan (RMS) } \\
\text { (Volt) }\end{array}$} & \multicolumn{3}{c|}{$\begin{array}{c}\text { THDv } \\
(\%)\end{array}$} & \multicolumn{2}{c|}{$\begin{array}{c}\text { Frequensi } \\
\text { Tegangan } \\
\text { (Hz) }\end{array}$} \\
\hline R & S & T & R & S & T & R & S & T \\
\hline 248,4 & 250,5 & 256 & 4,22 & 4,36 & 4,05 & 50 & 50 & 50 \\
\hline
\end{tabular}

Dari tabel5. terlihat bahwa hasil pengujian THDv terbesar terjadi pada phasa S sebesar $4,36 \%$ dan Vrms terbesar yaitu pada phasa T sebesar 256 volt.

Dari Hasil uji memperlihatkan bahwa kandungan THDv masih dalam batas yang ditetapkan oleh standar IEEE 519 - 1992 sebesar $5 \%$.

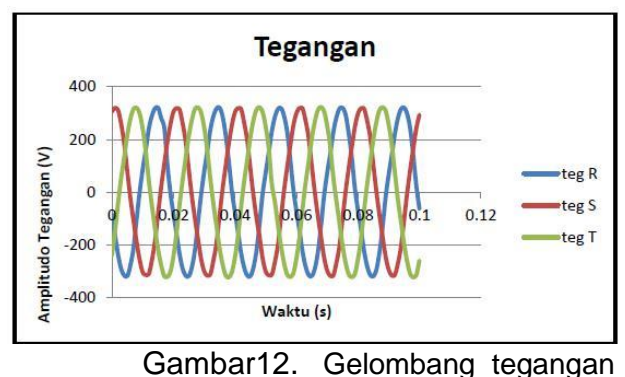

Hasil pengujian THDi, I rms dan frekwensi dengan beban linier dapat dilihat pada tabel6

Tabel 6. Hasil pengujian I.rms, dan waktu pemutusan MCB.

\begin{tabular}{|c|c|c|c|c|c|c|c|c|c|}
\hline \multicolumn{3}{|c|}{$\begin{array}{l}\text { Ar'us (RMS) } \\
\quad(\mathrm{mA})\end{array}$} & \multicolumn{3}{|c|}{$\begin{array}{l}\text { THDi } \\
(\%)\end{array}$} & \multicolumn{3}{|c|}{\begin{tabular}{|c|} 
Frequensy \\
Al'us \\
$(\mathrm{Hz})$ \\
\end{tabular}} & \multirow{2}{*}{$\begin{array}{c}\text { Waktu } \\
\text { Pemutusan } \\
\text { MCB } \\
\text { (detik) }\end{array}$} \\
\hline $\mathrm{R}$ & $S$ & $\mathrm{~T}$ & $\mathrm{R}$ & $S$ & $\mathrm{~T}$ & $\mathrm{R}$ & $\mathrm{S}$ & $T$ & \\
\hline 3197,5 & 3909,2 & 3503.3 & 1,82 & 1,05 & 3,11 & 50 & 50 & 50 & 127 \\
\hline
\end{tabular}

Dari tabel6, terlihat bahwa hasil pengujian I rms paling besar terjadi pada phasa $S$ sebesar 3909,2 mA dan THDi terbesar yaitu pada phasa $\mathrm{R}$ sebesari $1.82 \%$. Dari hasil pengujian tersebut bahwa kandungan harmonic arus THDi masih dalam batas yang ditetapkan oleh standar IEEE 519 -

1992 sebesar 5\%. Sedangkan waktu pemutusan rangkaian, MCB membutuhkan waktu 127 detik

\section{Analisa Hasil Pengujian}

Hasil pengujian $\mathrm{V}$ rms dengan beban Non linier dan beban linier dapat dilihat pada tabel7.

Tabel 7, hasil pengujia Vrms pada phasa R,S dan T dengan beban linier dan non linier.

\begin{tabular}{|c|c|c|c|}
\hline Phasa & $\begin{array}{c}\text { teg (RMS) Volt } \\
\text { Beban non linier }\end{array}$ & $\begin{array}{c}\text { teg (RMS) Volt } \\
\text { Beban linier }\end{array}$ & $\begin{array}{c}\text { Selisih } \\
\text { Tegangan (V) }\end{array}$ \\
\hline R & 283.3 & 248,4 & 34.9 \\
\hline S & 228.2 & 250,5 & -22.3 \\
\hline T & 281.3 & 256 & 25.3 \\
\hline
\end{tabular}

Pada tabel 7. menunjukan bahwa pada beban non linier, Vrms terbesar yaitu terjadi pada phasa $R$ sebesar 283.3 Volt dan pada beban linier Vrms terbesar terjadi pada phasa T sebesar 256 volt. Pada tabel 7 selanjutnya dibuat grafik seperti terlihat pada gambar 13.

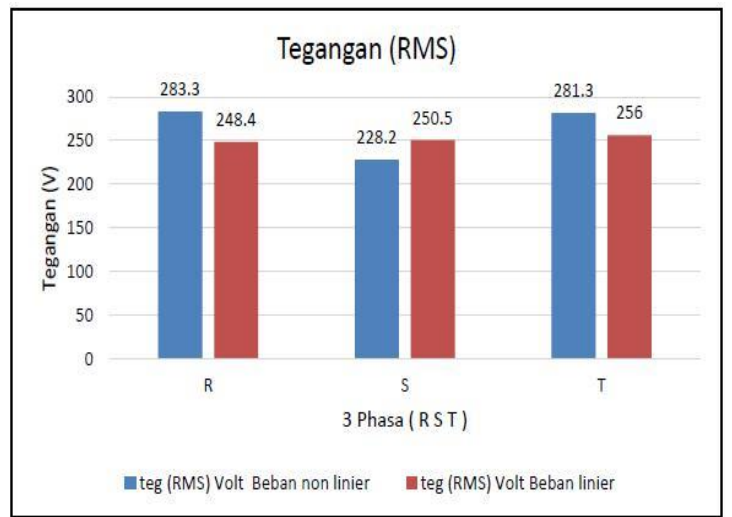

Gambar13 Grafik Vrms dengan beban linier dan non linier pada phasa R,S dan T.

Hasil pengujian I rms dengan beban Non linier dan beban linier dapat dilihat pada tabel8.

Tabel 8 Hasil pengujian Irms pada phasa $R, S$ dan $T$ dengan beban linier dan non linier 


\begin{tabular}{|c|c|c|c|}
\hline Phasa & $\begin{array}{c}\text { arus (RMS) } \\
\text { beban non linier } \\
\text { (mA) }\end{array}$ & $\begin{array}{c}\text { arus (RMS) } \\
\text { beban linier } \\
\text { (mA) }\end{array}$ & $\begin{array}{c}\text { Selisih arus } \\
\text { (mA) }\end{array}$ \\
\hline R & 3377.8 & 3197.5 & 180.3 \\
\hline S & 4383.6 & 3909.2 & 474.4 \\
\hline T & 2702.9 & 3503.3 & -800.4 \\
\hline
\end{tabular}

Data pada tabel8 diatas selanjutnya dibuat grafik seperti terlihat pada gambar 14 sebagai berikut

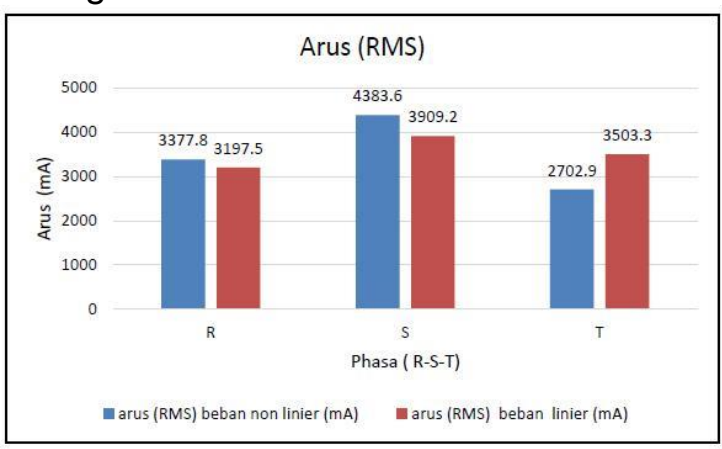

Gambar 14 Hasil uji Irms dengan beban linier dan non linier.

Hasil pengujian THDv dengan beban Non linier dan beban linier dapat dilihat pada tabel 9.

Tabel9 Hasil pengujian THDv dengan beban Linier dan non Linier

\begin{tabular}{|c|c|c|c|}
\hline Phasa & THDv \% non linier & THDv \% linier & Selisih THDv \% \\
\hline R & 7.87 & 4.22 & 3.65 \\
\hline S & 11.8 & 4.36 & 7.44 \\
\hline T & 6.23 & 4.05 & 2.18 \\
\hline
\end{tabular}

Hasil uji pada tabel9 .menujukan besar THDv terbesar dengan beban non linier terjadi pada phasa $\mathrm{S}$ sebesar $11,8 \%$, baik pada phasa $\mathrm{R}, \mathrm{S}$ dan $\mathrm{T}$, besarnya THDv tersebut sudah diluar batas yang dipersyaratkan IEE yaitu sebesar 5\%, sedangkan THDv terbesar dengan beban linier terjadi pada phasa S sebesar 4,36\%, baik pada phasa $R, S$ dan $T$ kandungan THDv dengan beban linier masih dalam batas yg diijinkan standar IEE.

Selanjutnya dibuat grafik seperti pada gambar15

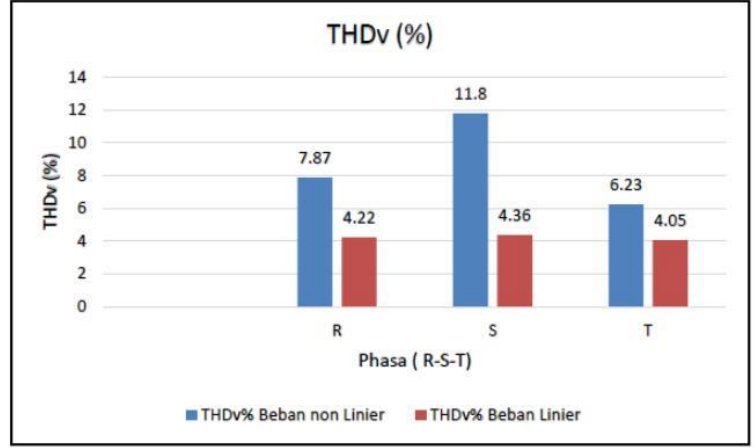

Gambar 15 Hasil uji THDV dengan beban linier dan non linier

Hasil pengujian THDi dengan beban Non linier dan beban linier dapat dilihat pada tabel10.

Tabel10 Hasil pengujian THDi dengan beban Linier dan non Linier

\begin{tabular}{|c|c|c|c|}
\hline Phasa & THDi \% non linier & THDi\% linier & Selisish THDi\% \\
\hline R & 4.9 & 1,82 & 3.08 \\
\hline S & 6.3 & 1,05 & 5.25 \\
\hline T & 6 & 3,11 & 2.89 \\
\hline
\end{tabular}

Hasil uji pada tabel 10 dengan beban non linier menujukan besar THDi terbesar terjadi pada phasa S sebesar 6,3\%. THDi pada phasa $S$ dan $T$ tersebut sudah diluar batas yang dipersyaratkan IEE yaitu sebesar 5\%.Pada beban linier THDi terbesar terjadi pada phasa $\mathrm{T}$ sebesar $3,11 \%$, kandungan THDi baik pada phasa R,S dan T masih dalam batas yg dipersyaratkan standar IEE

Perbandingan nilai THDi pada tabel 10 baik pada beban non linier dan non linier selanjutnya dibuat grafik gambar16.

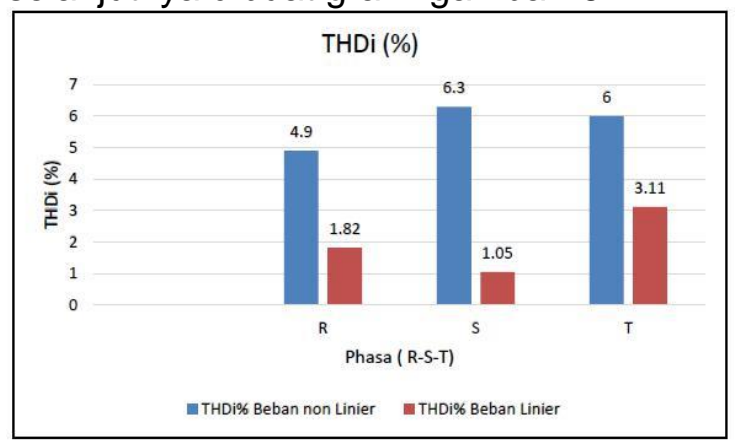

Gambar16. Hasil uji THDi dengan beban linier dan non linier.

Dari Gambar 16 bahwa nilai THDi lebih besar pada beban non linier 


\section{Analisa Faktor Daya Beban Linier Dan Beban Non Linier 3 A}

Faktor daya yang dinotasikan sebagai $\cos \varphi$ didefinisikan sebagai perbandingan antara arus yang dapat menghasilkan kerja didalam suatu rangkaian terhadap arus total yang masuk kedalam rangkaian atau dapat dikatakan sebagai perbandingan daya aktif $(\mathrm{kW})$ dan daya semu (kVA). Dalam pengujian pengaruh beban linier dan beban non linier terhadap MCB nilai faktor daya tersebut menjadi penting dalam proses analisa data. Berikut ini adalah hasil pengukuran $\operatorname{Cos} \varphi$ meter dapat dilihat pada tabel 11.

Tabel 11.Perbandingan $\operatorname{Cos} \varphi$ antara beban linier dan non linier $3 \mathrm{~A}$

\begin{tabular}{|c|c|}
\hline $\operatorname{Cos} \varphi$ Beban non linier & $\operatorname{Cos} \varphi$ Beban linier \\
\hline 0.90 & 0.98 \\
\hline
\end{tabular}

Dari tabel 11 , nilai cosphi $(\varphi)$ dengan beban non linier sebesar 0,90 dan pada beban linier sebesar 0,98. Ini menunjukan bahwa penggunaan beban induktif pada pengujian beban non linier mempengaruhi nilai $\cos \varphi$.

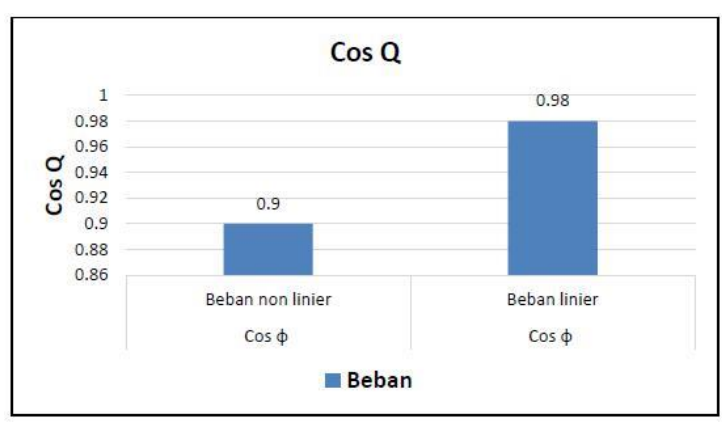

Gambar 17. Hasil uji $\cos$ phi $(\cos \varphi)$. dengan beban linier dan non linier.

\section{Anailsa besarnya Daya pada Beban Non Linier dan Beban Linier 3 A}

$$
\begin{aligned}
& \text { Perhiungan Daya pada Beban Non Linier } \\
& \text { Phasa } R \\
& \mathrm{P}=\mathrm{V}(\mathrm{RMS}) \times \mathrm{I}(\mathrm{RMS}) \times \operatorname{Cos} \varphi \\
& =283,3 \text { Volt } \times 3377,8 \mathrm{~mA} \times 0,90 \\
& =861,237 \mathrm{Watt} \\
& \text { Phasa S } \\
& \mathrm{P}=\mathrm{V}(\mathrm{RMS}) \times \mathrm{I}(\mathrm{RMS}) \times \operatorname{Cos} \varphi \\
& =228,3 \text { Volt } \times 4383,7 \mathrm{~mA} \times 0,90 \\
& =900,7 \text { Watt } \\
& \text { Phasa T }
\end{aligned}
$$

$\mathrm{P}=\mathrm{V}$ rms $\mathrm{X} I \mathrm{rms} X \operatorname{Cos} \varphi$

$=281,3$ Volt $X 2703 \mathrm{~mA} \times 0,90$

$=760,353 \mathrm{Watt}$

\section{Analisa besarnya Daya(P) pada Beban Linier}

Phasa R

$\mathrm{P}=\mathrm{V}(\mathrm{RMS}) \times \mathrm{I}(\mathrm{RMS}) \times \operatorname{Cos} \varphi$

$=248,4$ Volt $\times 3197,5 \mathrm{~mA} \times 0,98$

$=778,373 \mathrm{Watt}$

Phasa S

$\mathrm{P}=\mathrm{V}(\mathrm{RMS}) \times \mathrm{I}(\mathrm{RMS}) \times \operatorname{Cos} \varphi$

$=250,5$ Volt X 3909,2 $\mathrm{mA}$ X 0,98

$=959,669 \mathrm{Watt}$

Phasa T

$\mathrm{P}=\mathrm{V}(\mathrm{RMS}) \mathrm{XI}(\mathrm{RMS}) \times \operatorname{Cos} \varphi$

$=256$ Volt $X 3503.3 \mathrm{~mA} \times 0,98$

$=878,907 \mathrm{Watt}$

\section{Analisa besarnya Daya Total Beban Non Linier 3A \\ Daya total = Daya phasa $R+$ Daya Phasa $S$ \\ + Daya Phasa T \\ $=861,237$ Watt $+900,7$ Watt $+760,353$ Watt \\ $=2.522$ Watt}

\section{Perhitungan besar Daya Total Beban Linier \\ Daya total = Daya phasa $R+$ Daya Phasa $S$ \\ + Daya Phasa T \\ $=778,373$ Watt $+959,669$ Watt $+878,907$ \\ Watt \\ $=2.617$ Watt.}

Tabel 12.Perbandingan Daya aktip antara beban linier dan non linier $3 \mathrm{~A}$

\begin{tabular}{|c|c|c|}
\hline Phasa & Daya aktif(Watt) Beban non linier & Daya aktif(Watt)Beban linier \\
\hline R & 861,237 & 778,373 \\
\hline S & 900,7 & 959,669 \\
\hline T & 760,353 & 878,907 \\
\hline
\end{tabular}

Dari tabel 12 Besarnya daya aktif pada beban non linier terbesar terjadi pada phasa S sebesar 900,7 watt, dan pada beban linier pada phasa $S$ sebesar 959,669 watt Hasil tabel 12 selanjutnya dibuat gambar 18 . 


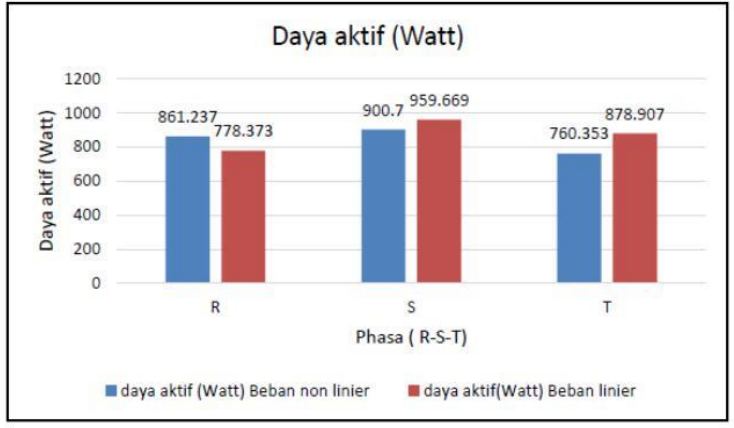

Gambar18 Grafik perbandingan Daya aktip dengan beban linier dan non linier

\section{Analisa Perbandingan Waktu Pemutusan MCB}

Tabel13.Perbandingan pemutusan MCB antara beban linier dan non linier

\begin{tabular}{|l|c|c|}
\hline \multicolumn{1}{|c|}{ Jenis Beban } & $\begin{array}{c}\text { Waktu Pemutusan } \\
\text { MCB(detik) }\end{array}$ & $\begin{array}{c}\text { Selisih Waktu } \\
\text { pemutusan MCB } \\
\text { (detik) }\end{array}$ \\
\hline Beban Non Linier & 48 & 79 \\
\hline Beban Linier & 127 & \\
\hline
\end{tabular}

Tabel 13 selanjutnya dibuat gambar grafik 19

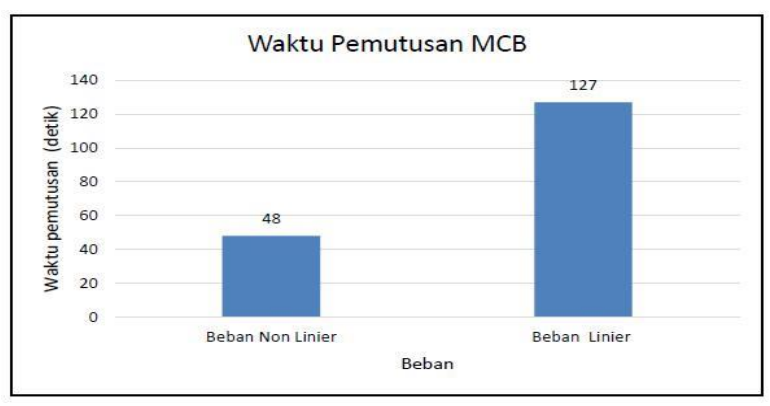

Gambar19 Perbandingan Pemutusan MCB antara beban linier dan non linier

Hasil uji pada gambar18 diperlihatkan waktu pemutusan MCB pada pembebanan 3 Amper antara beban linier dan beban non linier, bahwa pemutusan MCB dengan beban non linier lebih cepat 79 detik.

\section{KESIMPULAN}

Dari Hasil penelitian analisa pengaruh beban linier dan non linier terhadap fungsi MCB dapat disimpulan sebagai berikut

Pada beban non linier hasil pengujianTotal harmonisa tegangan (THDv) terbesar pada phasa S sebesar $11.8 \%$, dan Total harmonisa arus (THDi) terbesar pada phasa $S$ sebesar $6,3 \%$ sedankan waktu pemutusan MCB selama 48detik.

Besarnya harmonisa akan mempengaruhi fungsi kerja MCB dalam memutuskan

rangkaian, karena adanya rugi-rugi penghantar $\left(I^{2} R\right)$ yang terjadi pada Bimetal, sehingga Bimetal lebih cepat panas.

Pada beban non linier waktu memutuskan MCB lebih cepat 79 detik dibandingkan beban linier.

\section{UCAPAN TERIMAKASIH}

Ucapan terimakasih disampaikan kepada Bapak KaProdi Teknik Elektro Unpam yang telah memberi dukungan terlaksananya penelitian dan penulisan.

\section{DAFTAR PUSTAKA}

[1] Roger C. Dugan, Mark F. McGranagan, Surya Santoso, H.Wayne Beat. " Electric Power system Quality” Edisi Kedua. 2004 McGraw-Hill.

[2] Warman, Eddy. 2013 "Penentuan Faktor Pengali Sistem Pengukuran Analog Untuk Beban Non Linear." Jurnal Teknik Elektro Universitas Sumatra Utara.

[3] I Ketut Wijaya. "Penggunaan Dan Pemilihan Pengaman Mini Circuit

Breaker (MCB) Secara Tepat Menyebabkan Bangunan Lebih Aman Dari Kebakaran Akibat Listrik" Jurnal Teknologi Elektro. UNUD Vol. 6 No. 2 Juli - Desember 2007.

[4] IEEEStd519-1992"IEEE

Recommended Practices and Requirements for Harmonic Control in Electric Power Systems". IEEE Inc. 1993.

[5] De La Rosa, Francisco C. 2006. "Harmonisa And Power System". CRC Press.

[6] SPLN 108: 1993 tentang "Pemutus Tenaga Mini Untuk Pembatas dan Pengaman Arus Lebih Untuk Instalasi Gedung dan Rumah" Diterbitkan oleh DEPARTEMEN PERTAMBANGAN DAN ENERGI PERUSAHAAN UMUM LISTRIK NEGARA.

[7] Baron Jean Baptiste Joseph Fourier. 1822. "The Analytical Theory of Heat". 
[8] F. Suryatmo. 1992. "Dasar-dasar teknik listrik”, PT. RINEKA CIPTA.

[9] klocknermoeller.com/circuit.breakers/circ uit.breaker.../695007. "miniature circuit breakers - Klockner Moeller" di unduh padatanggal28May2016. 
